\title{
Comparison Pan Evaporation Data with Global Land-surface Evap- oration GLEAM in Java and Bali Island Indonesia
}

\author{
Trinah Wati, Ardhasena Sopaheluwakan and Fatkhuroyan
}

Received: Nov 2017 / Accepted: June 2018

(C) 2018 Faculty of Geography UGM and The Indonesian Geographers Association

\begin{abstract}
This paper evaluates the variability of pan evaporation (Epan) data in Java and Bali during 2003-2012 and compares to GLEAM (Global Land-surface Evaporation: the Amsterdam Methodology) data version v3.b namely actual evaporation (E) and potential evaporation (Ep) in the same period with statistical method. Gleam combines a wide range of remotely sensed observations to estimate the terrestrial evaporation and root-zone soil moisture at a global scale ( 0.25 -degree). The aim is to assess the accuracy of Gleam data by examining correlation, mean absolute error, Root means square error and mean error between Epan and Gleam data in Java and Bali Island. The result shows the correlation between Epan with Ep Gleam is higher than Epan with E Gleam. Generally, the accuracy of Gleam data is a good performance to estimate the land evaporation in Java and Bali at annual and monthly scale. In daily scale, the correlation is less than 0.50 both between Epan with E Gleam and between Epan with Ep Gleam. In a daily scale, the average errors ranging from 0.15 to $3.09 \mathrm{~mm}$ according to RMSE, MAE, and ME. The result of this study is essential in providing a valuable recommendation for choosing alternative evaporation data in a regional or local scale from satellite data.
\end{abstract}

Keywords: Pan evaporation, GLEAM evaporation, Java and Bali

Abstrak Makalah ini mengevaluasi variabilitas data evaporasi panci (Epan) periode 2003 - 2012 dan membandingkan dengan data Gleam (Global Land-surface Evaporation: the Amsterdam Methodology) versi v3.b yaitu evaporasi aktual (E) dan evaporasi potensial (EP) pada periode yang sama menggunakan metode statistik. Gleam merupakan kombinasi sejumlah data observasi penginderaan jauh untuk menduga evaporasi terestrial dan kelengasan tanah pada zona perakaran dengan skala global (0.25 derajat). Tujuan dalam penelitian ini adalah menilai keakuratan data Gleam menggunakan korelasi, mean absolute error (MAE), Root mean square error (RMSE) dan mean error (ME) antara Epan dengan data Gleam di Pulau Jawa dan Bali. Hasil penelitian menunjukkan korelasi Epan dengan Ep GLEAM leih tinggi dibandingkan Epan dengan E Gleam. Umumnya keakuratan data Gleam menunjukkan hasil yang cukup baik untuk menduga evaporasi lahan di Pulau Jawa dan Bali pada interval waktu bulanan dan tahunan. Untuk interval waktu harian, korelasi baik antara Epan dengan E Gleam maupun Ep Gleam kurang dari 0.5. Kesalahan (error) pada interval waaktu harian berkisar antara 0.15 hingga $3.09 \mathrm{~mm}$ berdasarkan nilai RMSE,MAE dan ME.. Hasil dari penelitian ini sangat penting sebagai rekomendasi untuk memilih alternatif data penguapan pada skala regional atau lokal menggunakan data satelit.

Kata kunci: Evaporasi Panci, evaporasi GLEAM, Jawa dan Bali.

\section{Introduction}

Evaporation refers to the process of the water status changing from liquid to vapor. In the hydrological cycle, evaporation is the transfer of water from the oceans and land surface to the atmosphere, as the first stage in the hydrological cycle and affects the water input into the land surface. Approximately $85 \%$ of evaporation on Earth occurs in the oceans [Mehta et al., 2005], evaporation flux magnitude smaller in land surface than the ocean, however, $60-70 \%$ of the volume of rainfall evaporated in land surface [Lim \& Roderick, 2009].

In applications of ecology, hydrology, agriculture, and engineering, the potential evaporation is proportional to the rate of water evaporates from a pan located at the surface, known as pan evaporation (Epan) [Roderick \& Farquhar, 2004]. Because of the broad of

Trinah Wati, Ardhasena Sopaheluwakan and Fatkhuroyan Indonesia Agency for Meteorology Climatology and Geophysics (BMKG), Jl Angkasa I no. 2 Central Jakarta, Indonesia Corresponding email: trinah.wati@gmail.com its applications, Epan is routinely measured by various agencies [Stanhill, 2002] and those data are used together with rainfall measurements to characterize the surface moisture balance. Pan evaporation measurement in Indonesia routinely uses Standardized US Class A pan by some agencies.

In accordance to detect global climate change, scientists have been conducted researches on global evaporation and evapotranspiration assessments to detect changes in the hydrological cycle and to estimate the impacts of climate change to water resources and deforestation [Miralles et al., 2011]. Precipitation and evapotranspiration will be affected by global climate change especially for renewable freshwater resources [Mu et al., 2011]. Accuracy in evapotranspiration estimation is necessary for applications of global environmental change research, basin-scale water resource management, and sustainable development of agriculture [Jia et al., 2012] and for projecting potential changes in the global hydrological cycle under different climate change scenarios [Teuling et al., 2009]. 
In recent years, estimation of evapotranspiration product from remote sensing has been developed [Allen et al., 2007; Courault et al., 2005; Glenn et al., 2007; Kalma et al., 2008; Li et al., 2009; Wang \& Dickinson, 2012]. The estimation used several models with categories:

- Surface energy balance models, with one-source and two-source, Surface Energy Balance Algorithm over Land (SEBAL) and Surface Energy Balance System (SEBS) [Alexandridis et al., 2009; Gibson et al., 2013; Jin et al., 2013; Ruhoff et al., 2012]

- Empirical statistical models involve relationships between evapotranspiration and vegetation indices [Glenn et al., 2007; Murray et al., 2009; Nagler et al., 2005; Tian et al., 2013]

- Estimation approaches that combined traditional with remote sensing [Cleugh et al., 2007; Fisher et al., 2011; Mu et al., 2011; Zhou et al., 2005]

In this study, we use Gleam data, estimated from remote sensing to compare with observational Epan data. Gleam (Global Land-surface Evaporation: the Amsterdam Methodology) is global land-surface evaporation estimated from multi-satellite observations within Priestley and Taylor-based framework. It combines a wide range of remotely sensed observations with some algorithms devoted to estimating the terrestrial evaporation and root-zone soil moisture at a global scale with 0.25 -degree spatial resolution. [Miralles et al., 2011].

This paper evaluates the climate of Epan during the 2003-2012 period in Java and Bali Island and compares it to Potential Evaporation (Ep) and Actual Evaporation (E) of Gleam data version v3.b. The aim is to assess the accuracy of Gleam data by examining statistical metric such as correlation, mean absolute error, root mean square error and mean error between Epan and Gleam data in Java and Bali Island. There is still insufficiency of Epan data availability for regional scale in Indonesia because of the lack number stations that observe Epan. This study tries to investigate the alternative of evaporation data from satellite (Gleam) for evaluation of the climatology of evaporation in regional scale where the stations are not available.

\section{The Methods}

Data employed in this study are Epan data and Gleam data version v3.1 from 2003 to 2012. The Epan's observational data are from 30 meteorological stations in Java and Bali Island. The position of the stations demonstrated in Figure 1, while the names of stations and data period presented in Table 1 . The pre-processing step of Epan data has conducted before analyzing by quality control checking and homogeneity test with Petitt, Standard Normal Homogeneity Test (SNHT), Buishand and Von Neumann [Wijngaard, et.al, 2003] using monthly Epan data.

The newest model is Gleam v3 produce three kinds of terrestrial evaporation and root-zone soil moisture datasets. Gleam v3.a is the first kind of datasets version based on soil moisture's observation satellites, vegetation optical depth and snow water equivalents, reanalysis air temperature and radiation, and a multisource precipitation product (1980-2014). The second version is v3.b based on observations from different passive and active C- and L-band microwave sensors European Space Agency Climate Change Initiative data sets (2003-2015) and the last one is v3.c that based on observations from the Soil Moisture and Ocean Salinity satellite (2011-2015) (Martens et al., 2016). Each data sets consist of different components of terrestrial evaporation, i.e. transpiration, bare-soil evaporation, open-water evaporation, interception loss and sublimation (Miralles et al., 2011). Each grid cell contains four different land-cover types: (1) bare soil, (2) low vegetation (e.g. grass), (3) tall vegetation (e.g. trees) and (4) open water (Martens et al., 2016).

The components of Gleam data version v3.b that compared to Epan are actual evaporation (E) and potential evaporation (Ep). The calculation of potential evaporation rate Ep ( $\mathrm{mm} /$ day) based on Priestley and Taylor (1972) using air temperature and net radiation and actual evaporation $\mathrm{E}(\mathrm{mm} /$ day) are converted from Ep depending on the land-cover type [Martens et al., 2016]. We extracted Gleam data v3.b grid with the nearest neighbor method according to the position the same as the Epan station sites and assess the accuracy with the point-to-grid approach.

The accuracy assessment of Gleam data uses following methods for daily scale data:

a. The linear correlation coefficient (CC) or the quantity of $r$, which measures the strength and the direction of a linear relationship between two variables. The linear correlation coefficient referred to the Pearson product moment correlation coefficient in honor of its developer Karl Pearson. The formula for computing $\mathrm{r}$ is :

$$
r=\frac{n \sum x y-\left(\sum x\right)\left(\sum y\right)}{\sqrt{n\left(\sum x^{2}\right)-\left(\sum x\right)^{2}} \sqrt{n\left(\sum y\right)-\left(\sum y\right)^{2}}}
$$

Where $\mathrm{n}$ is the number of pairs of data, $\mathrm{x}$ is Epan data and $y$ is Gleam data. The r-value may take between -1.0 and +1.0. A positive correlation is when $\mathrm{x}$ and $\mathrm{y}$ have a strong positive linear correlation, $\mathrm{r}$ is close to +1 . A negative correlation is when $\mathrm{x}$ and $\mathrm{y}$ have a strong negative linear correlation, $r$ is close to -1 . If there is no linear correlation or a weak linear correlation, $r$ is close to 0 . The $\mathrm{CC}$ analysis also conducted for monthly scale data.

b. The mean absolute error (MAE) refers to the average of the absolute deviation between the Gleam and Epan data values. Absolute error retains differences in magnitude that will be reduced because of the positive and negative differences will cancel each other to some degree. The range of MAE is 0 to infinity and the perfect score is 0 . The MAE formula is: 


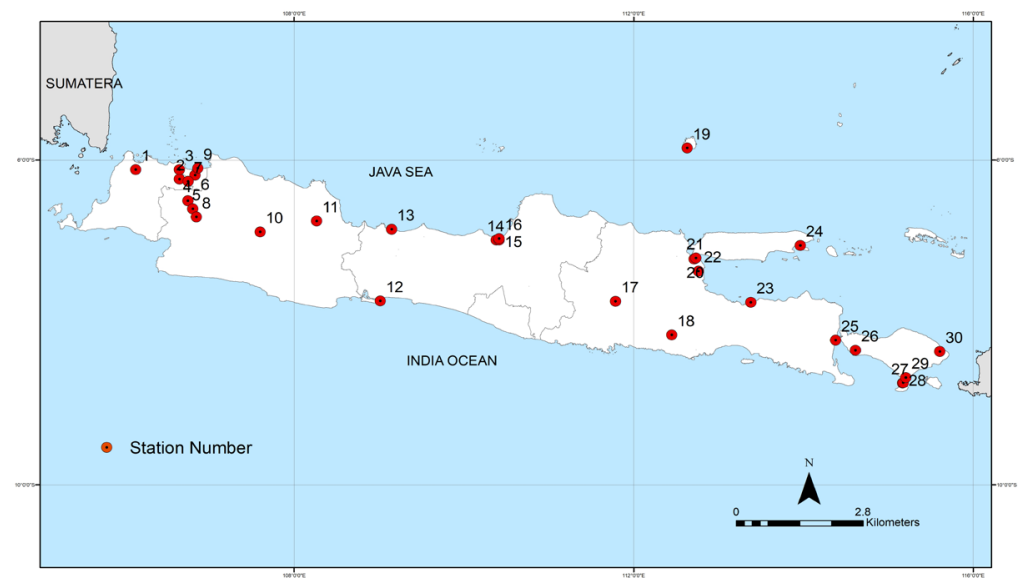

Figure 1. Location of station sites

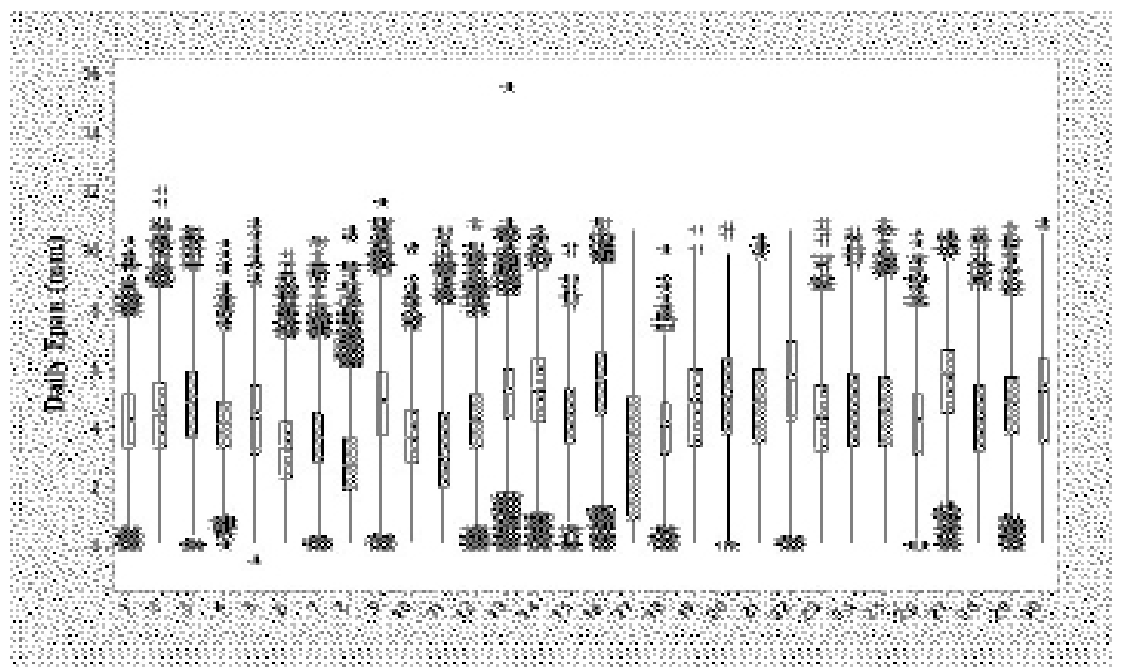

Figure 2. Boxplots of daily Epan data in Java and Bali

$$
M A E=\frac{1}{N} \sum_{n=1}^{N}\left|x_{n}-y_{n}\right|
$$

c. Root Mean Square Error (RMSE) is the standard deviation of the residuals. The range of RMSE is 0 to infinity and the perfect score is 0 . RMSE is a measure of how to spread out these residuals are and it is very essential for the analysis to verify experimental results.

RMSE $=\sqrt{\frac{1}{N} \sum_{n=1}^{N}\left(y_{n}-x_{n}\right)^{2}}$

d. Mean Error (ME) refers to the average of all the error in a set. An "error" is the difference between the Epan value and Gleam data value. The range of $\mathrm{ME}$ is 0 to infinity and the perfect score is 0 .

$M E=\frac{1}{N} \sum_{n=1}^{N}\left(x_{n}-y_{n}\right)$

\section{Result and Discussion}

Observation Data of Pan Evaporation in Java and Bali Island during 2003-2012 Period

The Climate rainfall in Java and Bali, according to Aldrian \& Susanto [2003] classified as Region A, which has one peak and one trough and experiences strong influences of two monsoons namely wet northwest monsoon from November to March and dry southeast monsoon from May to September. Northwest monsoon brings warm and wet air resulting from evaporation over the Java Sea and the South China Sea and becomes a source of precipitation. Otherwise, Southeast monsoon winds from the Australian Continent brings cold and dry air and little precipitation over Java Island.

There are two seasons in Java and Bali, because of monsoonal winds and the regions of maximum rainfall related to the intertropical convergence zone (ITCZ) that migrate across Java and Bali annually that alter the distinct of the wet season in boreal winter and the dry season in boreal summer, while the transition seasons are in between [Qian, et al, 2010]. Java Island is located 


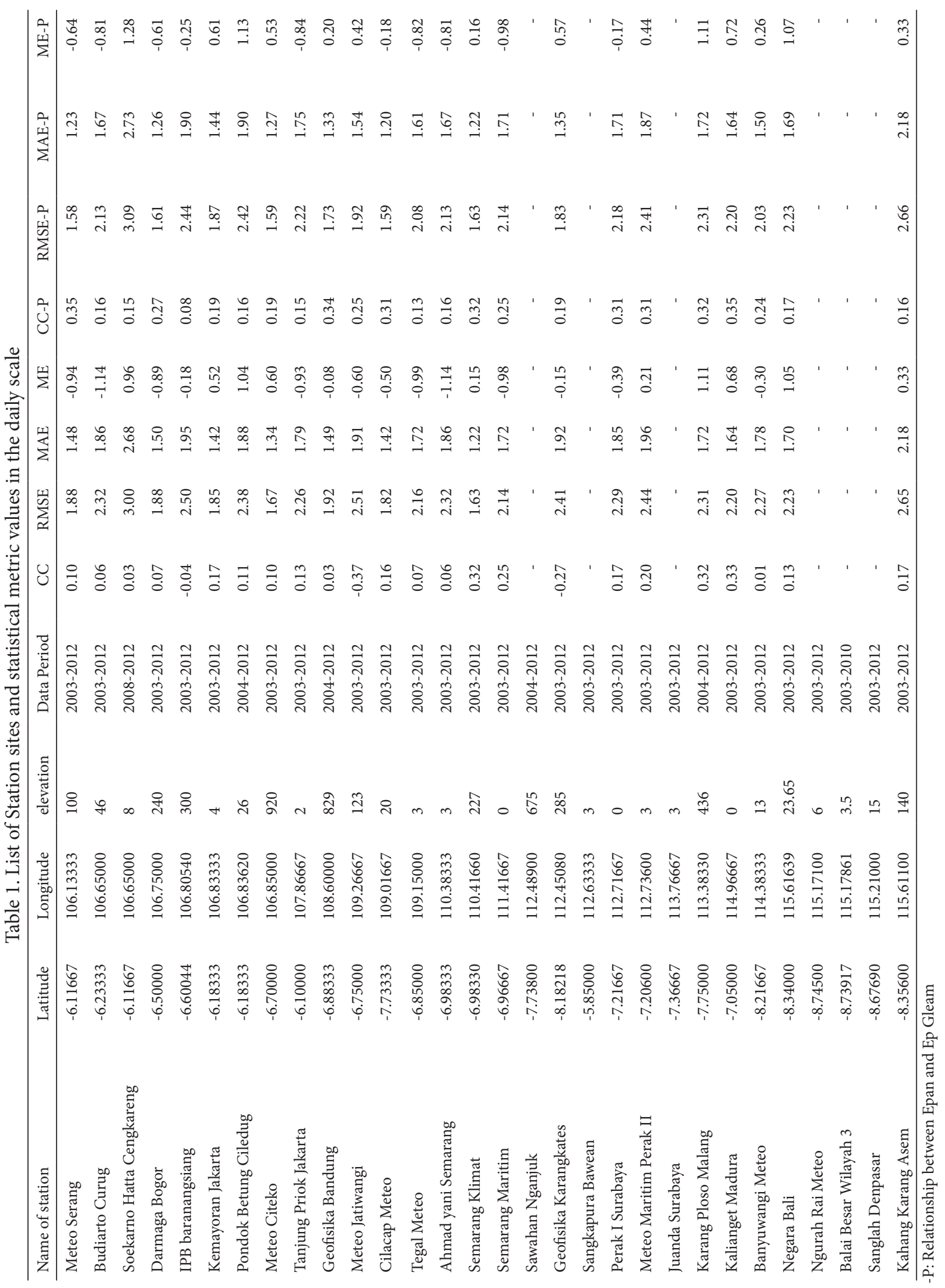




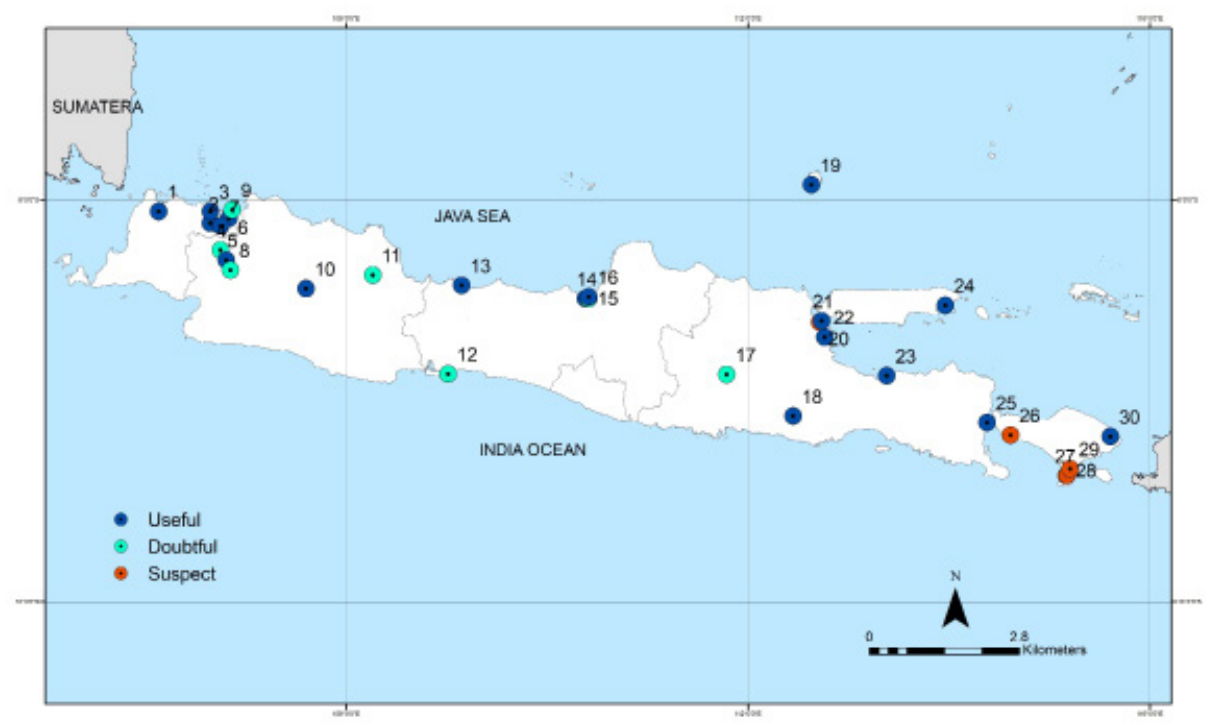

Figure 3. The result of homogeneity test
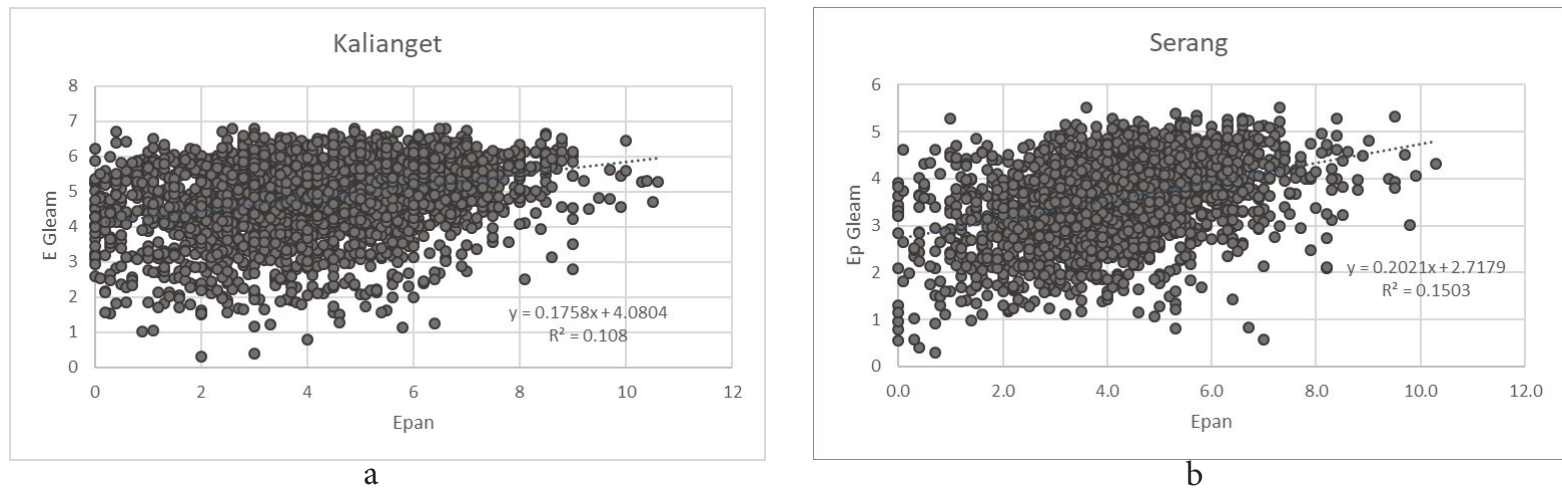

Figure 4. Plotting of daily Epan with daily E Gleam (a) and Ep Gleam (b) in Kalianget Station

in the center of Asian-Australian monsoon region in which a tropical climate of the southern hemisphere [Ramage 1968]. Furthermore, Bali is part of Lesser Sunda Island that located in the eastward from Java Island.

Observation data of pan evaporation (Epan) in Java and Bali Island 2003-2012 period have daily evaporation data ranged from $0 \mathrm{~mm}$ to $15.5 \mathrm{~mm}$ with a daily average between $2.9 \mathrm{~mm}$ to $5.5 \mathrm{~mm}$ and standard deviation ranged from 1.3 to $2.3 \mathrm{~mm}$. Median of daily evaporation data ranged from 2.7 to $5.8 \mathrm{~mm}$, 1st quartile ranged from 0.9 to $4.5 \mathrm{~mm}$ and the $3 \mathrm{rd}$ quartile ranged from 3.6 to $6.9 \mathrm{~mm}$ as demonstrated in Figure 2 . There were many outliers of the data so that we conducted the quality controls checking before the process of analyzing. We use the threshold Q3 $+3^{*} \mathrm{IQR}$ [Mayer, et.al, 2012; Supari, et.al, 2012] to eliminate the outlier more than the threshold value, which Q3 is the third quartile and IQR is an inter-quartile range.

The outliers of evaporation data were caused by some errors such as overflowed water in the pan, out of order equipment and unreasonable value after checking other climate parameter data [Wati, 2015]. Evaporation measurement with a pan is a raw measurement that has some potential fallacies such as pan environment bias, operator's bias, estimation of rainfall on the pan, reading error, and data recording error [Abtew et al., 2011].

The result of homogeneity test of monthly Epan data classified into three categories as Schönwiese \& Rapp [1997] and Wijngaard et al., [2003] classification. The classification depends on the number of tests rejecting the null hypothesis. The categories are:

- Class 1: 'useful' - one or zero tests reject the null hypothesis at the $1 \%$ level.

- Class 2: 'doubtful' - two tests reject the null hypothesis at the $1 \%$ level.

- Class 3: 'suspect' - three or four tests reject the null hypothesis at the $1 \%$ level.

Figure 3 demonstrates the result of homogeneity test. There are homogeneity breaks detected in station series labeled as class 2 or 'doubtful' about $23.3 \%$ and class 3 or 'suspect' is $16.7 \%$ in the period of Epan data. The Class 1 or 'useful' category is $60 \%$ of the station series. The explanation of the statistically detected 


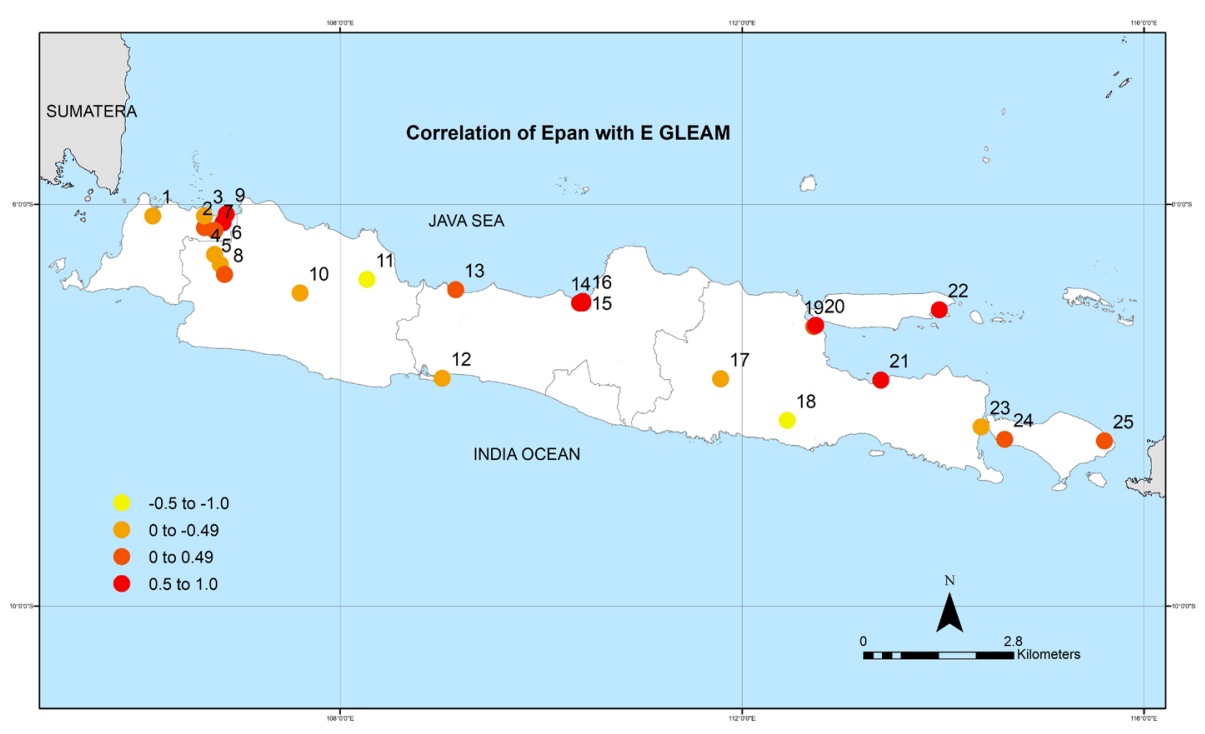

(a)

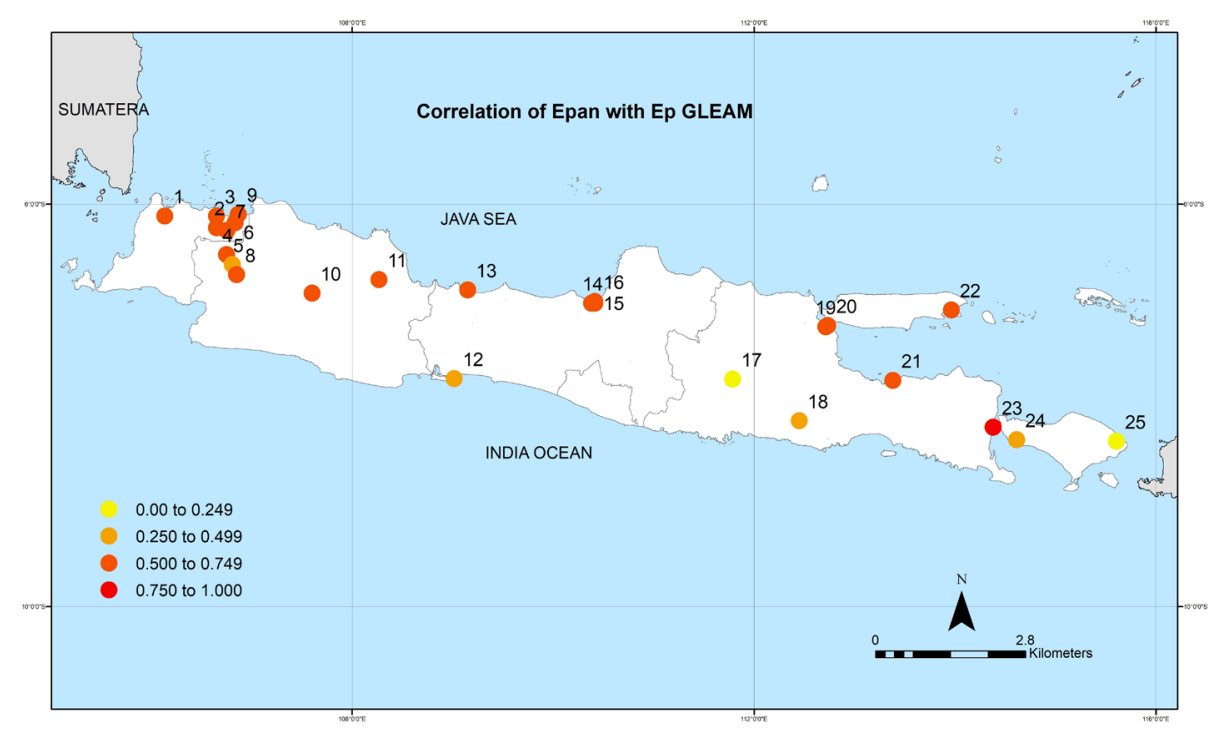

(b)

Figure 5. Correlation between Epan with E GLEAM and Ep GLEAM in monthly scale

as inhomogeneities of Epan data can be found by exploring the metadata of stations which need a more further study that unfortunately not included in this paper. The supporting information about historical metadata is important for detection and correction of homogeneity breaks even though the metadata are not always available because it is essential for climate change analysis [Wijngaard et al., 2003].

\section{Comparison between Epan and Gleam data}

The E Gleam daily data in Java and Bali range between 0.1 to $7.8 \mathrm{~mm}$, with the averages of 2.1 until 4.9 $\mathrm{mm}$. In addition, the Ep Gleam daily data range between 0.1 until $7.2 \mathrm{~mm}$ and the averages range from 3.3 to 4.9 $\mathrm{mm}$. There are only 25 stations of 30 station sites that qualified for statistical analysis, the eliminated stations are Sangkapura Bawean, Juanda Surabaya, Ngurah Rai, Balai Besar Wilayah 3 and Sanglah because the values of Gleam data cannot be extracted to compare with Epan. Table 1 represents daily scale statistical metric values, which consist of CC, RMSE, MAE and ME resulting from the relationship between Epan with E Gleam and Epan with Ep Gleam during 2003-2012. The CC is relatively low for daily scale and the values are less than 0.50 on average for all the years both between Epan with E Gleam and between Epan with Ep Gleam.

The CC between Epan and E Gleam ranged from -0.37 to 0.33 with an average of 0.09 , mostly they have 
Ahmad Yani

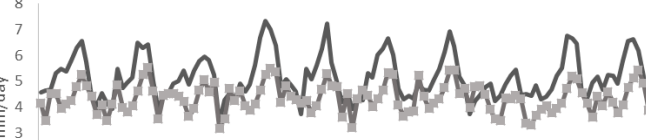

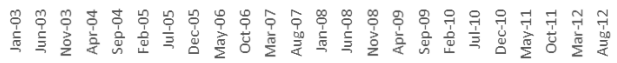

—Epan - - E Gleam

(a)
Ahmad Yani

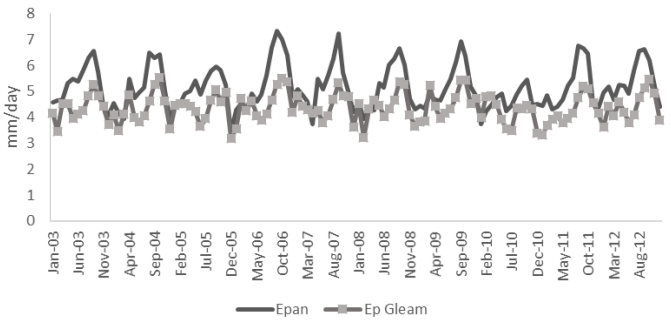

(b)

Figure 6. Plotting monthly average of Epan with monthly E Gleam (a) and Ep Gleam (b) in Ahmad Yani Station
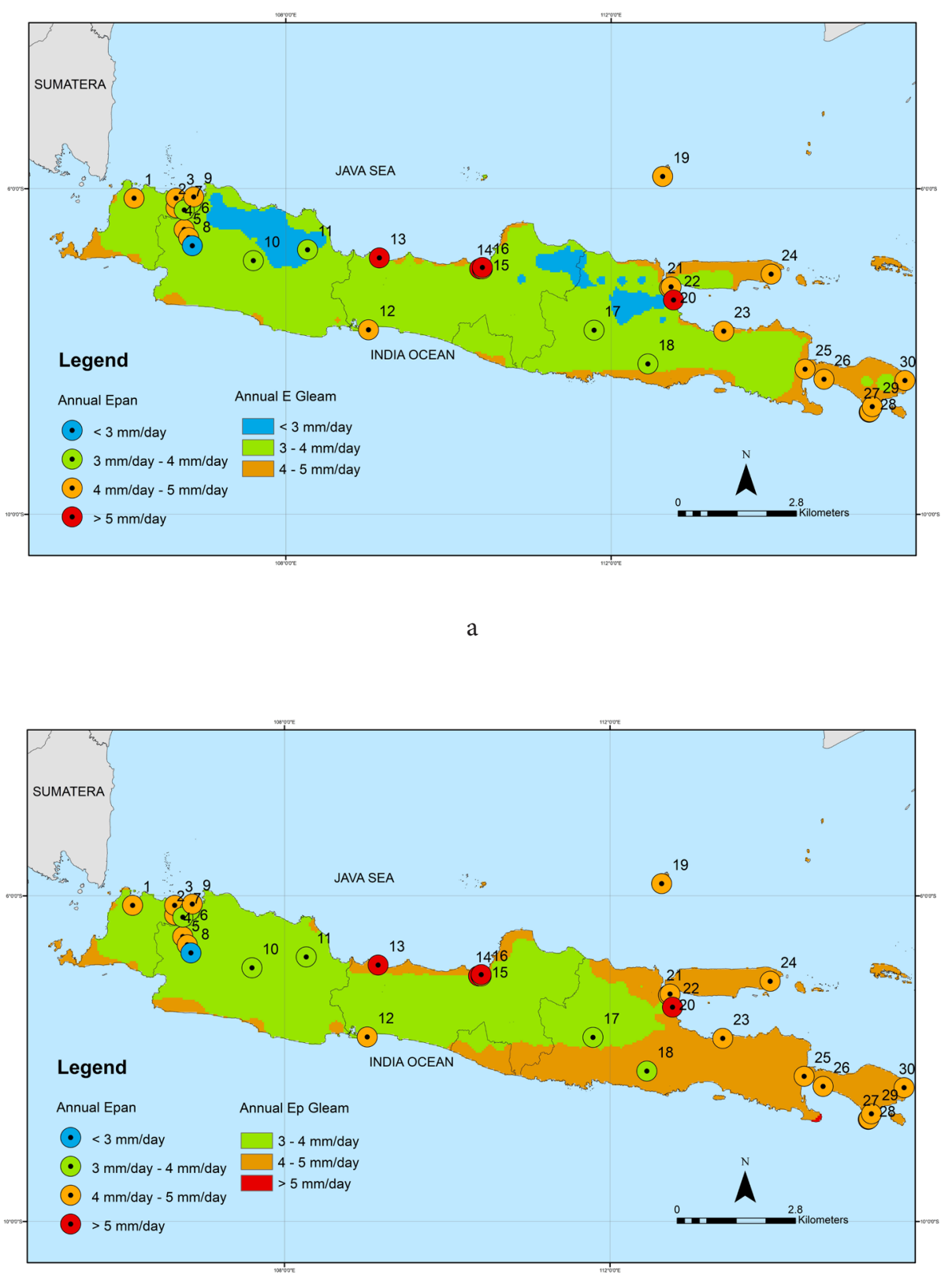

b

Figure 7. Mean annual Epan compare to annual E Gleam (a) and annual Ep Gleam (b) $(\mathrm{mm} /$ day) in Java and Bali Island 
positive correlation even though $16 \%$ of stations have a negative correlation, while the CC between Epan and Ep Gleam have a positive correlation that ranged from 0.08 to 0.35 with an average of 0.22 . Figure 4 illustrates the linear regression Epan and E Gleam (a) and Epan and Ep Gleam (b) in Kalianget which have the highest value of CC. The Figures expose the variation of daily Epan in the $\mathrm{X}$-axis, which has a wider range than $\mathrm{E}$ and Ep Gleam in the y-axis. The RMSE of E Gleam and Ep Gleam in relation with Epan in daily scale have the same variation as seen in Table 1. RMSE between Epan with E Gleam ranged from 1.63 to 3.00 and the average of 2.23, while RMSE between Epan with Ep Gleam ranged from 1.58 to 3.09 with the average of 2.11 .

The ME of E Gleam in relation with Epan in daily scale ranged from -1.14 to 1.11 and the average of -0.10 , while ME of Ep Gleam with Epan ranged from -0.98 to 1.28 and the average of 0.15 . The MAE of E Gleam and Ep Gleam with Epan also have the same variation. The MAE of E Gleam with Epan ranged from 1.22 to 2.68 with average 1.77, while The MAE of Ep Gleam with Epan ranged from 1.20 to 2.73 and the average of 1.65.

Figure 5 represents the CC in monthly scale between Epan with E and Ep Gleam. The CC in monthly scale is higher than daily scale, the CC between Epan with $\mathrm{E}$ Gleam has variation both negative and positive value. The highest negative $\mathrm{CC}$ is -0.74 in Jatiwangi and the positive one is 0.72 in Ahmad Yani Semarang and Semarang Maritim, while the lowest CC is -0.01 in Cengkarang. The stations that have negative monthly CC are $40 \%$ of all stations. This relationship indicates Epan decreases while the rising of actual evaporation in some stations because the moist of air over waterfilled in the pan is increasing and the evaporation from the pan decrease, which also found in some previous studies [Brutsaert \& Parlange, 1998; Liu et al, 2009].

Furthermore, the CC between Epan with Ep Gleam is positive. The highest CC is 0.77 in Banyuwangi and the lowest CC is Kahang. The stations located in the northern part of Java, are higher than the southern part of Java, which has CC more than 0.50 .

Figure 6 demonstrates plotting of monthly average in $\mathrm{mm}$ /day during 2003 - 2012 period of Epan with E Gleam (a) and Epan with Ep Gleam (b) in Ahmad Yani Station that has highest monthly CC. The variability of E Gleam and Ep Gleam underestimated from Epan.

The annual mean of Epan, E Gleam, and Ep Gleam presented in Figure. 7 to compare the distribution of Epan (dot) and E Gleam (polygon) in Fig. 7a and that between Epan (dot) and Ep Gleam (polygon) in Fig.7b. The performance of annual mean of E Gleam and Ep Gleam more similar with Epan in the Eastern part of Java, some stations in western part of Java and all stations in Bali. This performance is essential to improve the information of evaporation in regional scale by merging or blending the Epan data with satellite data (Gleam) to learn the distribution of evaporation in some place that does not have observational instruments and to overcome the limitations of climate stations in the vast territory of Indonesia.

Previousstudy comparingglobalevapotranspiration data of GIMMS (Global Inventory Modeling and Mapping Studies) satellite dataset using normalized difference vegetation index (NDVI) product with global evapotranspiration estimated at the tower, the result showed RMSE ranged 13.0-15.3 mm/month with R2 $=0.80-0.84$ [Zhang et al, 2010]. Evaluation three kinds of global evaporation namely PenmanMonteith products of Moderate Resolution Imaging Spectroradiometer (MODIS), Gleam and the PriestleyTaylor Jet Propulsion Laboratory model (PT-JPL) found that Gleam and PT-JPL more realistic compare to that from ERA-interim and the model tree ensemble (MTE) [Miralles et al., 2016].

\section{Conclusion}

From 2003 until 2012 data period, Epan in Java and Bali have daily mean evaporation range from 2.9 $\mathrm{mm}$ to $5.5 \mathrm{~mm}$, while E Gleam daily average range from 2.1 to $4.9 \mathrm{~mm}$. In addition, the mean daily of Ep Gleam range from 3.3 to $4.9 \mathrm{~mm}$. The variability of Gleam data underestimates compare to Epan. The estimation of evaporation both actual and potential using Gleam data have good performance in annual average in some stations in western part of Java, and all stations in Bali and eastern part of Java. The monthly average of the potential evaporation has a better correlation than the actual evaporation to monthly Epan. The estimation of Gleam data is realistic for Java and Bali Island, the merging or blending process between Gleam data with observation data from Epan are very recommended improving accurate and consistent estimation of pan evaporation which very essential component for integrated water resource management.

\section{Acknowledgment}

The GLEAM data gained from https://www. gleam.eu. The authors acknowledge BMKG and IPB meteorology station for providing data intended for this study.

\section{References}

Abtew, W., Obeysekera, J., \& Iricanin, N. (2011). Pan evaporation and potential evapotranspiration trends in South Florida. Hydrological Processes, 25(6), 958-969. https://doi.org/10.1002/hyp.7887.

Aldrian, E., \& Dwi Susanto, R. (2003). Identification of three dominant rainfall regions within Indonesia and their relationship to sea surface temperature. International Journal of Climatology, 23(12), 1435-1452. https://doi.org/10.1002/joc.950.

Alexandridis, T. K., Cherif, I., Chemin, Y., Silleos, G. N., Stavrinos, E., \& Zalidis, G. C. (2009). Integrated methodology for estimating water use in mediterranean agricultural areas. Remote Sensing, 1(3), 445-465. https://doi.org/10.3390/rs1030445. 
Allen, R. G., Tasumi, M., Morse, A., Trezza, R., Wright, J. L., Bastiaanssen, W., ... Robison, C. W. (2007). Satellite-Based Energy Balance for Mapping Evapotranspiration with Internalized Calibration (METRIC) - Applications. Journal of Irrigation and Drainage Engineering, 133(4), 395-406. https://doi. org/10.1061/(ASCE)0733-9437(2007)133:4(395).

Brutsaert, W., \& Parlange, M. B. (1998). Hydrologic cycle explains the evaporation paradox [8]. Nature, 396(6706), 30. https://doi.org/10.1038/23845.

Cleugh, H. A., Leuning, R., Mu, Q., \& Running, S. W. (2007). Regional evaporation estimates from flux tower and MODIS satellite data. Remote Sensing of Environment, 106(3), 285-304. https://doi. org/10.1016/j.rse.2006.07.007.

Courault, D., Seguin, B., \& Olioso, A. (2005). Review on estimation of evapotranspiration from remote sensing data: From empirical to numerical modeling approaches. Irrigation and Drainage Systems, 19(3), 223-249.

Fisher, J. B., Whittaker, R. J., \& Malhi, Y. (2011). ET come home: Potential evapotranspiration in geographical ecology. Global Ecology and Biogeography, 20(1), 1-18. https://doi.org/10.1111/ j.1466-8238.2010.00578.x.

Gibson, L. A., Jarmain, C., Su, Z., \& Eckardt, F. E. (2013). Estimating evapotranspiration using remote sensing and the surface energy balance system - A South African perspective. Water SA, 39(4), 477484. https://doi.org/Doi 10.4314/Wsa.V39i4.5.

Glenn, E. P., Huete, A. R., Nagler, P. L., Hirschboeck, K. K., \& Brown, P. (2007). Integrating Remote Sensing and Ground Methods to Estimate Evapotranspiration. Critical Reviews in Plant Sciences, 26(3), 139-168. https://doi.org/10.1080/07352680701402503.

Jia, Z., Liu, S., Xu, Z., Chen, Y., \& Zhu, M. (2012). Validation of remotely sensed evapotranspiration over the Hai River Basin, China. Journal of Geophysical Research Atmospheres, 117(13), 1-21. https://doi.org/10.1029/2011JD017037.

Jin, X., Guo, R., \& Xia, W. (2013). Distribution of actual evapotranspiration over Qaidam basin, an Arid area in China. Remote Sensing, 5(12), 6976-6996. https://doi.org/10.3390/rs5126976.

Kalma, J. D., McVicar, T. R., \& McCabe, M. F. (2008). Estimating land surface evaporation: A review of methods using remotely sensed surface temperature data. Surveys in Geophysics, 29(4-5), 421-469. https://doi.org/10.1007/s10712-008-9037-Z.

Li, Z. L., Tang, R., Wan, Z., Bi, Y., Zhou, C., Tang, B., ... Zhang, X. (2009). A review of current methodologies for regional Evapotranspiration estimation from remotely sensed data. Sensors, 9(5), 3801-3853. https://doi.org/10.3390/s90503801.

Lim, W. H., \& Roderick, M. L. (2009). An Atlas of the Global Water Cycle.

Liu, B., Ma, Z., Xu, J., \& Xiao, Z. (2009). Comparison of pan evaporation and actual evaporation estimated by land surface model in Xinjiang from 1960 to 2005. Journal of Geographical Sciences, 19(4), 502512. https://doi.org/10.1007/s11442-009-0502-5.

Martens, B., Miralles, D. G., Lievens, H., Schalie, R. Van Der, Jeu, R. A. M. De, Fernández-prieto, D., ... Verhoest, N. E. C. (2016). GLEAM v3 : satellite-based land evaporation and root-zone soil moisture, (August), 1-36. https://doi.org/10.5194/ gmd-2016-162.

Mayer, D., Steiner, A., \& Steinacker, R. (2012). Innovations and applications of the VERA quality control. Geoscientific Instrumentation, Methods and Data Systems, 1(2), 135-149. https://doi. org/10.5194/gi-1-135-2012.

Mehta, V. M., DeCandis, A. J., \& Mehta, A. V. (2005). Remote-sensing-based estimates of the fundamental global water cycle: Annual cycle. Journal of Geophysical Research Atmospheres, 110(22), 1-14. https://doi.org/10.1029/2004JD005672.

Miralles, D. G., De Jeu, R. A. M., Gash, J. H., Holmes, T. R. H., \& Dolman, A. J. (2011). Magnitude and variability of land evaporation and its components at the global scale. Hydrology and Earth System Sciences, 15(3), 967-981. https://doi.org/10.5194/ hess-15-967-2011.

Miralles, D. G., Holmes, T. R. H., Jeu, R. A. M. De, Gash, J. H., Meesters, A. G. C. A., \& Dolman, A. J. (2011). Global land-surface evaporation estimated from satellite-based observations. Hydrology and Earth System Sciences, (2), 453-469. https://doi. org/10.5194/hess-15-453-2011.

Miralles, D. G., Jeu, R. A. M. De, Gash, J. ., Holmes, T. R. ., \& Dolman, A. . (2011). An application of GLEAM to estimating global evaporation, 1-27. https://doi. org/10.5194/hessd-8-1-2011.

Miralles, D. G., Jiménez, C., Jung, M., Michel, D., Ershadi, A., Mccabe, M. F., ... Fernández-Prieto, D. (2016). The WACMOS-ET project - Part 2: Evaluation of global terrestrial evaporation data sets. Hydrology and Earth System Sciences, 20(2), 823-842. https://doi.org/10.5194/hess-20-8232016.

Mu, Q., Zhao, M., \& Running, S. W. (2011). Improvements to a MODIS global terrestrial evapotranspiration algorithm. Remote Sensing of Environment, 115(8), 1781-1800. https://doi. org/10.1016/j.rse.2011.02.019.

Murray, R. S., Nagler, P. L., Morino, K., \& Glenn, E. P. (2009). An Empirical Algorithm for Estimating Agricultural and Riparian Evapotranspiration Using MODIS Enhanced Vegetation Index and Ground Measurements of ET. II. Application to the Lower Colorado River, U.S. Remote Sensing, 1(4), 1125-1138. https://doi.org/10.3390/rs1041125

Nagler, P. L., Cleverly, J., Glenn, E., Lampkin, D., Huete, A., \& Wan, Z. (2005). Predicting riparian evapotranspiration from MODIS vegetation indices and meteorological data. Remote Sensing 
of Environment, 94(1), 17-30. https://doi. org/10.1016/j.rse.2004.08.009.

Roderick, M. L., \& Farquhar, G. D. (2004). Changes in Australian pan evaporation from 1970 to 2002. International Journal of Climatology, 24(9), $1077-$ 1090. https://doi.org/10.1002/joc.1061.

Ruhoff, A. L., Paz, A. R., Collischonn, W., Aragao, L. E. O. C., Rocha, H. R., \& Malhi, Y. S. (2012). A MODIS-based energy balance to estimate Evapotranspiration for clear-sky days in Brazilian tropical savannas. Remote Sensing, 4(3), 703-725. https://doi.org/10.3390/rs4030703.

Schönwiese, C.-D., \& Rapp, J. (1997). Climate Trend Atlas of Europe Based on Observations 1891-1990. SPRIGER-SCIENCE+Business MEDIA, B.V.

Stanhill, G. (2002). Is the class A evaporation pan still the most practical and accurate meteorological method for determining irrigation water requirements? Agricultural and Forest Meteorology, 112(34), 233-236. https://doi.org/10.1016/S01681923(02)00132-6.

Supari, Sudibyakto, Ettema, J., \& Aldrian, E. (2012). Spatiotemporal Characteristics of Extreme Rainfall Events over Java Island, Indonesia. Case: East Java Province, 44(1). Retrieved from http://itc.nl/ library/papers_2012/msc/aes/supari.pdf.

Teuling, A. J., Hirschi, M., Ohmura, A., Wild, M., Reichstein, M., Ciais, P., ... Seneviratne, S. I. (2009). A regional perspective on trends in continental evaporation. Geophysical Research Letters, 36(2), 1-5. https://doi.org/10.1029/2008GL036584

Tian, J., Su, H., Sun, X., Chen, S., He, H., \& Zhao, L. (2013). Impact of the spatial domain size on the performance of the ts-vi triangle method in terrestrial evapotranspiration estimation. Remote Sensing, 5(4), 1998-2013. https://doi.org/10.3390/ rs5041998.
Wang, K., \& Dickinson, R. E. (2012). A review of global terrestrial evapotranspiration: Observation, modeling, climatology, and climatic variability. Reviews of Geophysics, 50(2). https://doi. org/10.1029/2011RG000373.

Wati, T. (2015). Kajian Evaporasi Pulau Jawa dan Bali Berdasarkan Data Pengamatan 19752013. IPB Bogor University of Agriculture. Retrieved from http://repository.ipb.ac.id/ handle/123456789/79057.

Wijngaard, J. B., Klein Tank, A. M. G., \& Können, G. P. (2003). Homogeneity of 20th century European daily temperature and precipitation series. International Journal of Climatology, 23(6), 679692. https://doi.org/10.1002/joc.906.

Zhang, K., Kimball, J. S., Nemani, R. R., \& Running, S. W. (2010). A continuous satellite-derived global record of land surface evapotranspiration from 1983 to 2006. Water Resources Research, 46(9), 1-21. https://doi.org/10.1029/2009WR008800.

Zhou, H., Liu, S., Sun, R., Li, M., \& Lu, L. (2005). Estimation of regional evapotranspiration in the $\mathrm{Mu}$ Us Sandland. International Geoscience and Remote Sensing Symposium (IGARSS), 6(1963), 4419-4421. https://doi.org/10.1109/ IGARSS.2005.1525899. 